\title{
Evaluation of Multi-Drug Resistant Tuberculosis Predictor Index in Surakarta, Central Java
}

\author{
Putri Pamungkas'), Setyo Sri Rahardjo²), Bhisma Murti1) \\ 1) Masters Program in Public Health, Universitas Sebelas Maret \\ 2) Faculty of Medicine, Universitas Sebelas Maret
}

\begin{abstract}
Background: Tuberculosis (TB) remains a global public health problem. New cases of lung Tuberculosis in 2015 were 10.4 million worldwide. One of the challenging in TB control to be addressed is the development of Multi Drug Resistant Tuberculosis (MDR-TB). There were an estimated 15,380 TB cases in Indonesia by 2015 with 1,860 positive TB cases and 1,566 cases successfully treated. This study aimed to determine the predictor index for MDR-TB.

Subjects and Method: This was an analytic observational study with a case-control design. The study was conducted at Dr. Moewardi Hospital, Surakarta, Central Java, from August to November 2017. The study subjects were selected by fixed disease sampling including 75 MDR-TB patients and 75 TB patients. The dependent variable was MDR-TB. The independent variables were medical history, co-morbidity (Diabetes Mellitus), drug side effect, drug-taking supervisor, and regularity of treatment. The data were collected by questionnaire and medical record. The data were analyzed by a multiple logistic regression.

Results: MDR-TB Occurrence Index increased with drug-taking supervisor $(b=2.33$; 95\% CI= 3.83 to 27.91; $\mathrm{p}<0.001)$, drug-side effect $(\mathrm{b}=0.73 ; 95 \% \mathrm{CI}=0.58$ to $7.45 ; \mathrm{p}=0.026)$, medical history $(b=2.35 ; 95 \% C I=3.80$ to $29.38 ; p<0.001)$. MDR-TB Occurrence Index decreased by absence of type 2 Diabetes Mellitus $(b=-0.56 ; 95 \% C I=0.18$ to $1.78 ; p=0.033)$, regular treatment $(b=-1.73$; $95 \% \mathrm{CI}=0.06$ to $0.46 ; \mathrm{p}<0.001)$.

Conclusion: MDR-TB Occurrence Index is determined by drug-taking supervisor, drug-side effect, medical history, Type 2 Diabetes Mellitus, and regular treatment.

Keywords: MDR-TB Occurrence Index, medical history, drug-taking supervisor, drug-side effect, Type 2 Diabetes Mellitus, regular treatment

\section{Correspondence:}

Putri Pamungkas. Masters Program in Public Health, Universitas Sebelas Maret. Jl. Ir.Sutami No. 36 A, 57126, Surakarta, Central Java.Email: pamungkasputri95@gmail.com.

\section{BACKGROUND}

Tuberculosis is still a global health problem. By 2015, there were 10.4 million new tuberculosis cases worldwide. Tuberculosis already affects $30 \%$ of the world's population. The highest transmission is found in males which was about 5.9 million (59\%), while in women, it was in the second place for about 3.5 million (34\%), followed by children for about 1 million (10\%) (World Health Organization, 2016). Every year, there are 1.8 deaths caused by tuberculosis,

Asia as the world's highest infection spread. The Asian region contributes approximmately $20 \%$ of deaths caused by tuberculosis, especially in developing countries such as India, Indonesia and China (World Health Organization, 2016). The high incidence of tuberculosis that leads to decreased quality of life and the impacts caused to death, causes tuberculosis to be a health problem that must be stopped, especially in developing countries, including Indonesia (Ginandjar et al., 2016).
\end{abstract} and transmission continues to expand in 
Journal of Epidemiology and Public Health (2018), 3(2): 263-276

https://doi.org/10.26911/jepublichealth.2018.03.02.06

Many factors that cause high incidence of tuberculosis consisting of external factors and internal factors. External factors that influence such as distance health care and the environment that supports treatment in patients with tuberculosis. Internal factors may be affected by the treatment of the patient (Abouyannis et al., 2014). Patient obedience in doing the treatment plays an important role in the success of tuberculosis treatment because it can cause resistance to tuberculosis germs so anti-tuberculosis drugs (OAT) can not prevent the spread of tuberculosis or called Multi Drug Resistant Tuberculosis (MDRTB) (Liu et al. 2015).

Multi Drug Resistant Tuberculosis occurs when tuberculosis germs are resistant to first-line OAT, at least two drugs are isoniazid and rifampicin (McClintock et al., 2017). WHO estimates the prevalence of MDR-TB about 440,000 cases annually in the world with a mortality rate of around 150,000. About 8.5\% have been found and treated. In Indonesia, which is included in the category of High Burden Countries ranked 12th highest tuberculosis sufferers in the world, there are 8,900 cases of TB. $2 \%$ of MDR TB cases are estimated to come from new TB cases and $14.7 \%$ of TB cases are re-treated (WHO, 2016). MDR-TB in Indonesia in 2015 with 15,380 cases, 1,860 confirmed cases, and 1,566 treated (Infodatin, 2015).

Indonesia is in the 9th place with the incidence of tuberulosis in 2015 and in 12th place in 2016 (World Health Organization, 2016). Early detection is important to prevent the transmission of MDR-TB incidence. Drug Resistant Survey (DRS) results indicate that in Central Java, $1.8 \%$ MDR-TB was found in newborn tuberculosis cases and $17.1 \%$ were found in TB cases who received treatment (DRS, 2016). Based on preliminary study at Moewardi hospital, it is known that in 2015 MDR-TB patients who did treatment were 1839 visits, in 2016, there were 1.793 visits and in 2017, there were 1.466 periods January to May. Resistance can occur by various factors, such as inadequate therapy or treatment (Bradley et al., 2015).

Tuberculosis Drug Resistance (OAT) is strongly associated with a history of treatment experienced. Although in some cases primary resistance is found, the highest prevalence of MDR-TB spread still indicates that patients who have had previous treatment are at high risk of MDRTB. Patients with previous medical history had 4 times greater likelihood of resistant resistance and for MDR-TB 10 times greater than non-treated patients (Nagu et al., 2015). The length of TB treatment makes the patient saturated to run the treatment, then there is an important role of companion for the medication to monitor and remind the patients in the treatment. Resistance will be easy if the treatment is irregular and many treatment meetings are missed (Tola et al., 2016).

The late diagnosis is suspected to be the causie of a wider spread of drug resistance strains. The wrong implementation of TB treatment can be done by the patient, especially in the compliance of OAT consumption. Termination of early treatment is often encountered because the patient often states that they do not need to consume it, and the early discontinuation of drugs can cause resistance. One that can be done to detect early MDR-TB incidence is by making a predictor that can be used in looking at factors that are high risk for the occurrence of resistance to tuberculosis germs (Denkinger, Pai and Dowdy, 2014).

Treatment of tuberculosis in Indonesia is still below $85 \%$, especially in central java province which has only $75 \%$ successful treatment of tuberculosis. One of 
the success of tuberculosis treatment is that there is no resistance in the patients. Therefore, the researchers are interested in making a predictor as a tool to prevent the occurrence of MDR-TB in the form of MDR-TB Event Index.

\section{SUBJECTS AND METHOD}

The research design used was case control. The target population was all tuberculosis and MDR-TB patients. The location of the research was in Dr. Moewardi hospital, Surakarta in August-November 2017. The population was MDR-TB patients who had been treated in Dr. Moewardi hospital. While the control population was tuberculosis patients who had been treated in Dr. Moewardi hospital. The inclusion criteria were that the patients are able to complete the process of taking and able to answer well / no psychiatric disorders. While the exclusion criteria were all TB patients cured and MDR-TB patients aged under 15 years.

The sampling technique was simple random sampling with 150 samples using a 1: 1 ratio. The number of case samples was 75 MDR-TB patients and control samples were 75 tuberculosis patients.

The independent variables were comorbidities (Diabetes Mellitus), drug side effects (ESO), drug taking supervisor, distance of health care, previous medical history, health, contact history, and characteristics of study subjects (age, gender, education, occupation). The dependent variable was MDR-TB.

MDR-TB was defined as resistant TB sufferers based on the results of the molecular rapid test examination recorded at Moewardi hospital.

Drug taking supervisor was defined as the presence of the drug swallowing supervisor during treatment. Companion
Disease (Diabetes Mellitus) was defined as the presence of DM disease that accompanies the patient during the course of running the TB treatment.

Drug Side Effects (ESOs) was defined as the effects of tuberculosis drugs taken by respondents during the course of $\mathrm{TB}$ treatment.

Distance of health services was defined as the time of the respondent from the home of the patient tothe health care for TB treatment.

Previous medical history was the final result of treatment done by respondents after getting TB treatment.

Health behavior was defined as someone who consumes alcohol and smokes and never gets BCG immunization. Contact history is health behavior.

The research ethics include research approval, anonymity, confidentiality and Ethical approval. Ethical clearance in this study was conducted in Moewardi hospital.

Data collection techniques used were medical record data and questionnaires, then interviews were conducted directly to respondents for qualitative data collection. The steps in performing data analysis were using influence analysis between independent variable to dependent variable using bivariate and multivariate analysis. Bivariate analysis was used to determine the level of significance of independent and dependent variable influence by using Chi Square test. Chi square test aims to find out the eligible and unqualified variables to be continued on multivariable analysis.

\section{RESULTS}

\section{Sample characteristics}

Characteristics of subjects in this study can be seen in table 1 . 
Journal of Epidemiology and Public Health (2018), 3(2): 263-276

https://doi.org/10.26911/jepublichealth.2018.03.02.06

Table 1. The Distribution of Study Subjects

\begin{tabular}{|c|c|c|c|c|c|}
\hline \multirow{2}{*}{ No } & \multirow{2}{*}{ Characteristics } & \multicolumn{2}{|c|}{ Case } & \multicolumn{2}{|c|}{ Control } \\
\hline & & $\mathbf{N}$ & $\%$ & $\mathbf{n}$ & $\%$ \\
\hline \multirow[t]{3}{*}{1.} & Gender & & & & \\
\hline & Male & 50 & 29.1 & 122 & 70.9 \\
\hline & Female & 26 & 19.7 & 106 & 80.3 \\
\hline \multirow[t]{3}{*}{2.} & Education & & & & \\
\hline & Low & 43 & 28.7 & 107 & 71.3 \\
\hline & High & 33 & 21.4 & 121 & 78.6 \\
\hline \multirow[t]{3}{*}{3.} & Occupation & & & & \\
\hline & Not working & 13 & 19.4 & 54 & 80.6 \\
\hline & Working & 63 & 26.6 & 174 & 73.4 \\
\hline \multirow{3}{*}{4.} & Marital Status & & & & \\
\hline & Single & 11 & 21.6 & 40 & 78.4 \\
\hline & Married & 65 & $25 \cdot 7$ & 188 & 74.3 \\
\hline \multirow[t]{3}{*}{5 . } & Smoking & & & & \\
\hline & Smoking & 52 & 36.4 & 91 & 63.6 \\
\hline & Not smoking & 24 & 14.9 & 137 & 85.1 \\
\hline \multirow[t]{3}{*}{6.} & Alchohol & & & & \\
\hline & Alcohol & 22 & 40.0 & 33 & 60.0 \\
\hline & No alcohol & 54 & 21.7 & 195 & 78.3 \\
\hline \multirow[t]{3}{*}{7.} & Contact & & & & \\
\hline & Contact & 18 & 43.9 & 23 & 56.1 \\
\hline & No contact & 58 & 22.1 & 205 & 77.9 \\
\hline
\end{tabular}

Table 1 shows that most of the subjects of the study were male, for about 44 subjects or $58.7 \%$ in the case group. This is similar to the control group that most of the research subjects were male sex that is about 45 subjects or $60 \%$.

For the education, in the case group, it can be interpreted that most of the subjects were low educated that was about 39 subjects or equal to $52.0 \%$. While in the control group, most of them awee highly educated which was 40 subjects or $53.3 \%$ of the number of research subjects.

It can be interpreted that most of the research case group that is 48 subjects or equal (64.0\%) were $\geq 41$ years. In the control group, it showed that 47 subjects or total $(62.7 \%)$ were $>41$ years.

Almost all of the research subjects in the case group work which was 53 subjects or $70.7 \%$ and most of the study subjects also work. While in the control group, there were 52 research subjects or $69.3 \%$.

\section{Multivariate Analysis}

The result of multivariate analysis is shown in Figure 2. Of the 12 variables that are modeling candidates, there are 7 variables that are not included in the modeling. These variables do not go into modeling because the level of significance is more than 0.05 namely gender, education, service distance, BCG history, occupation, smoking, and age.

There was a negative effect of age and the risk of MDR-TB occurrence ( $b=-0.25$; CI95\% $=0.30$ to $3.01 ; \mathrm{p}=0.618$ ).

There was a negative relationship between sex and the risk of MDR-TB occurrence $(b=-0.03$; CI95\% $=0.30$ to 3.01; $\mathrm{p}=0.949)$.

There was a negative relationship between education and the risk of MDR-TB occurrence $(b=-0.32$; CI95\% $=0.28$ to $1.81 ; \mathrm{p}=0.490)$.

There is a positive relationship between work and the risk of MDR-TB occurrence $(b=0.31$; CI95\% $=0.41$ to 4.55 ; $\mathrm{p}=0.603)$.

There was a positive correlation between BCG history and the risk of MDRTB occurrence $(b=1.06$; $\mathrm{CI} 95 \%=0.80$ to 10.44; $\mathrm{p}=0.102$ ). 
There was a negative relationship between the distance of health care and the risk of MDR-TB occurrence $(b=-0.52$; CI95\% $=0.23$ to $1.51 ; \mathrm{p}=0.275$ ).

There was a positive effect of smoking on the risk of MDR-TB occurrence ( $\mathrm{b}=$ 1.18; CI95\% $=1.26$ to $8.44 ; \mathrm{p}=0.143$ ).

There was a negative association between Diabetes Mellitus disease and the risk of MDR-TB incidence was statistically significant $(b=-0.56$; CI95\% $=0.18$ to 1.78 ; $\mathrm{p}=0.033)$.

There was a positive effect between PMO on the risk of MDR-TB occurrence (b = 2.33; CI95\% = 3.83 to 27.91; $\mathrm{p}<0.001$ ).

There was a positive effect between drug side effects and the risk of MDR-TB occurrence $(b=0.73$; CI95\% $=0.58$ to 7.45 ; $\mathrm{p}=0.026)$.

Table 2. Multivariate results on the MDR-TB determinants using multiple logistic regression

\begin{tabular}{lcccc}
\hline \multirow{2}{*}{ Variable } & Regression & \multicolumn{2}{c}{ 95\% CI } & p \\
\cline { 3 - 4 } & Coefficient & Lower Limit & Upper Limit & \\
\hline No diabetes mellitus & -0.56 & 0.18 & 1.78 & 0.033 \\
No drug taking advisor & 2.33 & 3.83 & 27.91 & 0.000 \\
No side effect & -0.73 & 0.58 & 7.45 & 0.026 \\
Never forget & -1.73 & 0.06 & 0.46 & 0.000 \\
Drop out & 2.35 & 3.80 & 29.38 & 0.000 \\
Gender:Female & -0.03 & 0.30 & 3.01 & 0.949 \\
Education $\geq$ SHS & -0.32 & 0.28 & 1.81 & 0.490 \\
Services distance $\geq 15$ Menit & -0.52 & 0.23 & 1.51 & 0.275 \\
No BCG history & 1.06 & 0.80 & 10.44 & 0.102 \\
Not working & -0.31 & 0.41 & 4.55 & 0.603 \\
Smoking & 1.18 & 1.26 & 8.44 & 0.143 \\
Age $\geq 45$ years old & -0.25 & 0.30 & 3.01 & 0.618 \\
\hline
\end{tabular}

There was a negative relationship between treatment regulation and the risk of MDR-TB occurrence ( $\mathrm{b}=-1.73$; CI95\% = 0.06 to $0.46 ; \mathrm{p}<0.001)$.

There was a positive relationship between previous treatments and the risk of MDR-TB occurrence $(\mathrm{b}=2.35$; CI95\% = 3.80 to 29.38 ; $\mathrm{p}<0.001)$.

\section{MDR-TB occurence Index}

Variables with significance below 0.05 are further incorporated in the logistic grain model. From the analysis results, the index of the incidence of MDR-TB was found.

Index $=-3.67+1.73$ (Treatment Order) + 2.33 (Drug Swallowing) + 0.73 (Side Effects of Drug) +0.56 (Diabetes Mellitus) + 2.35 (Previous Treatment).

\section{DISCUSSIONS}

\section{Age}

There was an age influence between MDRTB group and non MDR-TB group. This is in line with a study conducted by (Lin et al., 2016) stating that there is a relationship between age and MDR-TB incidence. The results of this study were in line with a theory of Soerdiawan (2015) saying that the most age group of MDR-TB patients is at the age of more than 40 years.

Age cannot be included in MDR-TB incidence index because in multivariate test the level of significance is more than 0.005. Age can have an effect on MDR-TB but it is not significant to predict whether an elderly person can be at a greater risk than younger age for MDR-TB. This is in line with a study of Jia et al., (2014) stating that young or old age has a risk of MDR-TB because at a 
Journal of Epidemiology and Public Health (2018), 3(2): 263-276

https://doi.org/10.26911/jepublichealth.2018.03.02.06

young age TB sufferers have a productive age to work so often forget in taking drugs and finally Drop out in treatment. While in old age vital organs decrease in function so that they have the same risk.

\section{Gender}

The number of male respondents in this study is more than the female ones in both MDR-TB and non MDR-TB. The results of this study indicated that there was a gender effect between MDR-TB group and nonMDR-TB group. The results are in line with (Outhred et al., 2017)'s study stating that most of the gender of the respondents in the MDR-TB group and the non-MDR-TB group was the male ones and Suwanpimolkul et al. (2017) also noted that the majority of MDR-TB sufferers are male.

MDR-TB patients are dominated by men due to many factors, including because males tend to be disobedient during treatment with OAT. This disobedience can lead to resistance to OAT (Bello, 2010).

Although the majority of MDR-TB sufferers are male, it does not rule out that women remain at risk for TB-MDR. This can happen because of gender inequalities in which women have limited access to health services (World Health Organization, 2013).

\section{Education}

There was a significant relationship between MDR-TB and education. Another study done by Mediana (2002) resulting similar thing, which stated that educational level has a relationship with the incidence of drop out in TB patients. A high level of education can affect the level of TB patient adherence in doing anti-TB drugs (ATD) treatment. The higher a person's level of education, the higher the tendency to adhere to the treatment with ATD. Conversely, the lower the level of knowledge, the lower the tendency of TB patients to obedient in doing a treatment with ATD.
This was because the higher the educational level of TB patients, then it was assumed the higher the level of understanding of the respondents about the illness as well as the understanding of the instructions given by medical experts related to the consumption of ATD.

Although the majority of MDR-TB sufferers have low level of education, it did not rule out that high education has sufficient knowledge of MDR-TB occurrence (Efsen et al., 2018).

\section{Employment}

There was a significant relationship between MDR-TB and employment. Employment would affect the TB treatment of TB patients due to medication adherence for 6 months, sometimes workers were busy and forget the schedule of drug consumption. If the patients missed the drug consumption schedule for one time, it would lead to the failure in treatment (Fox et al., 2017). This is in line with a study by Mohd, Azhar and Kamaludin, (2015), which stated that workers have high mobility and busyness, therefore, patients tend to be disobedient in running the treatment by using ATD (Yates et al., 2016).

Although the majority of MDR-TB criteria were working patients, the same is true for non-workers of pulmonary TB patients who would also be busy looking for job or busy with their homework to support their living, therefore, there was no difference in employment status between non-working and working people with pulmonary TB (Mediana, 2002).

\section{Diabetes Mellitus Disease}

There was a relationship between MDR-TB and Diabetes Mellitus. TB patients who have diabetes mellitus history have higher risk to have MDR-TB than TB patients who did not have diabetes mellitus history. This was in line with a study by Arockiaraj et al., (2018) which stated that the occurrence of 
MDR-TB in patients who have TB with diabetes mellitus was 11.3 times greater than those without TB diabetes mellitus.

The conditions of high blood glucose levels can affect the achievement of drugs in the tissues and can also interfere with the function of alveolar macrophage cells (Bashar et al., 2016). Disruption of alveolar macrophage cell function would decrease the immune system. The decrease in the immune system caused TB germs in the lungs to be resistant to the drugs. TB patients with diabetes mellitus were likely to suffer gastrointestinal damage affecting the absorption of ATD of rifampicin so that their concentration in TB patients with DM can not be maximized and this lead to a poor outcome of $\mathrm{TB}$ treatment and may cause drug resistance (Matteelli et al., 2017).

\section{HIV/AIDS}

A study by Suchindran et al. (2009) stated that there was a relationship between HIV and MDR-TB. The relationship between HIV/AIDS and drug resistance cases in TB patients was because of the immunity status of TB patients that may decrease the effectiveness of treatment using ATD and therefore, it enhanced the risk of drug resistance (Sight 2010).

\section{Drugs Taking Supervisor}

There was a significant relationship between MDR-TB and drug taking supervisor. This study was in line with a study by Soebarko (2017) which stated that drug taking supervisor affected the incident of MDR-TB. TB patients without drug taking supervisor have 19 times higher risk than TB patients who have drug taking supervisor. TB treatment took a long time and should be done every day. In addition, TB treatment would also cause side effects for those who consume it and would cause a sense of boredom and saturation. It was the boredom and saturation that would cause
TB sufferers to stop their treatment which would give them a greater chance of becoming MDR-TB.

Drug taking supervisor was one of the successful factors of DOTS program and the successful of therapy because it would affect the adherence of TB patients in taking ATD so that the patients were motivated to take medicine regularly. Drug taking supervisor was needed to ascertain whether the drug was actually taken or not (Burner, 2017).

\section{Health Services Distance}

There was a significant relationship between MDR-TB and the distance of health services. Although statistically the travel time did not affect the occurrence of MDR-TB, but the location of the TB patient's residence to the health service would affect the TB patients' regularity in the treatment process. TB patients who live far away from the service center would find the difficulty in taking the medication every month. The long travel time of respondents indicated that the access to health services was also far and took longer time. The result of this study was in line with a study by Sondakh (2014), which stated that there was a relationship between the distance to health services with the occurence of MDRTB. Prolonged travel time may be considered as one of the causes of tuberculosis sufferers to not perform routine treatment at the nearest health service center (Pedriacan, 2017).

\section{Alcohol Consumption}

Health behavior of alcohol consumption did not affect the occurrence of MDR-TB, because there was no difference between health behavior of alcohol consumption on MDR-TB groups and non MDR-TB. This was because Indonesian people, especially in Surakarta considered drinking alcohol as a thing that is prohibited by religion. 
Journal of Epidemiology and Public Health (2018), 3(2): 263-276

https://doi.org/10.26911/jepublichealth.2018.03.02.06

The result of this study was in line with Fauziah (2003), who stated that there was no relationship between alcohol consumption and the occurrence of MDRTB. In contrast to the results of a study conducted by Trinnawoottipong (2012) in Thailand, which stated that TB patients who drink alcohol as their habit have 5.1 times higher risk to become MDR-TB.

\section{Smoking}

There was a significant relationship between MDR-TB and smoking. According to the research by Barroso et al. (2003), there was an effect between smoking behavior and the occurrence of MDR-TB and smoking was one of the risk factors of MDR-TB. Continuous smoking behavior would result in disruption of the lung defense system that affected the destruction of alveolar macrophages so that it decreased the immune system. The decrease of the immune system caused TB germs in the lungs to be resistant to the drugs.

Acquired drug resistency lead to the organ damage which was not caused by smoking. To ensure that smoking was a risk factor for MDR-TB in TB patients, data on the age at first time smoking and the duration of smoking history were required (the number of cigarette per day, the content of cigarettes and the type of cigarette) (Riza, 2015).

\section{BCG History}

There was a significant relationship between MDR-TB and BCG history. This was in contrast with a study done by Sondakh (2014), which stated that there was no effect of BCG immunization status marked by a scar on the occurrence of MDR-TB. BCG immunization was effective to prevent miliary $\mathrm{TB}, \mathrm{TB}$ meningitis and TB spondylitis in children. BCG immunization was given to provide the protection against tuberculosis. BCG immunization caused active immunity to prevent the development of TB germs in the occurrence of infection (Basic Health Research, 2010). BCG immunization only provide protection against tuberculosis bacterial infection, it was not for drug-resistant tuberculosis germs due to errors in the treatment. Some of the causes of MDR-TB were due to inadequate drug use and irregular treatment (Hermina, 2013).

\section{Medical History of Regular Treatment}

There was a relationship between MDR-TB and the regular treatment. In an interview conducted to MDR-TB patients in this study, the irregularity or non-compliance of respondents in drinking ATD was because the respondents often forget to drink ATD. In addition, some respondents complained about TB services in poor health services. The irregularity of TB patients in previous treatment periods would result in genetic mutations of $\mathrm{M}$ tuberculosis so that anti-TB drugs were not effective against TB germs. When anti-TB drugs were no longer effective against TB germs, the chances of becoming an MDR-TB would be greater (Sarwani, 2012).

\section{Previous Treatment}

There was a relationship between MDR-TB and the previous treatment. This was in line with Mulisa (2015), who stated that there was an effect of failure or drop out previous TB treatment outcomes with the occurrence of MDR-TB. TB patients with a failed or dropped out history of TB treatment had a 3.5 times higher risk than those with TB who had recovery history of treatment outcome. Drop out or failure of TB treatment was one of the causes of drug resistance. TB treatment performed for more than two months can lead to the drop out for the patient because after intensive treatment, patients usually feel healed and they would stop the treatment. 
Previous therapy outcomes such as drop-outs can show the non-adherence of TB patients in implementing TB treatment, and it would increase the risk of MDR-TB, whereas previous TB treatment outcomes such as cured and complete treatment can show TB patients' adherence to treatment so that the risk of MDR-TB was smaller (Pinto and Carvalho, 2017).

\section{Drug-Side Effect}

There was a significant relationship between MDR-TB and drug-side effect. The result of this study was in line with a study by Lee et al., (2014), which stated that the side effect of ATD was the risk factor of MDR-TB. Factors relating to adherence treatment of pulmonary tuberculosis patients with control case design showed a significant relationship between drug side effects with adherence of pulmonary tuberculosis patients to regular treatment. Pulmonary TB sufferers who feel the side effects of drugs have the opportunity to stop the treatment.

Pulmonary TB sufferers who feel the side effects of ATD tend to stop the treatment (McBryde et al., 2017), this condition lead the TB sufferers into drop out. When TB patients do not perform the treatment completely, it would occur genetic mutation of M. tuberculosis bacteria which was resistant to ATD (Kigozi et al., 2017).

\section{Contact History}

Based on the interview results to the respondents, most of them admitted that they have no contact to TB sufferers and did not know whether the people around them have MDR-TB or not. This study was in line with a study by Fox et al., (2017), which stated that there was no relation between contact history and the occurrence of MDRTB. Contact history had no effect in this study because all respondents in the MDRTB group had a previous history of $\mathrm{TB}$ disease, where the outcome of previous TB treatment was a failure or drop out.

\section{Model of MDR-TB Index}

Based on multivariate analysis result using multiple logistic regression, the most influencing factor on MDR-TB occurrence in Surakarta was the availability factor of DSC, the regularity of ATD consumption, adverse side effects of ATD, previous TB treatment outcomes and comorbidities of diabetes mellitus. These five factors were the indicators in the preparation of MDR-TB occurrence index. Formula of MDR-TB occurrence index in Surakarta.

This prediction index can predict the risk of MDR-TB occurrence in Surakarta with $93.4 \%$ sensitivity and $80.3 \%$ specificity with measurement accuracy by $89.3 \%$. This prediction index can be used to predict the occurrence of MDR-TB in people with TB. Based on this, the MDR-TB risk management that can be implement was to identify the most risky variables to TB patients. The findings in this study can be implemented to the MDR-TB disease prevention program by intervening in the socialization of the most influencing factors on the occurrence of MDR-TB. The implementation of MDR-TB occurrence index in Surakarta can be used by the officers both at health service level and health department by using MDR-TB occurrence index algorithm.

\section{Evaluation of MDR-TB Occur- rence Index}

This study evaluated the steps in the cycle, which consist of reviewing the findings, developing the research results, conducting field trials, and revising the results obtained (Mohd et al., 2015).

The assessment of MDR-TB occurrence index

The result of this study was the MDR-TB occurrence index that can be predicted whether it has high or low risk to become 
Journal of Epidemiology and Public Health (2018), 3(2): 263-276

https://doi.org/10.26911/jepublichealth.2018.03.02.06

MDR-TB. It was expected that this index can be used to be screening tools in determining high-risk populations of MDRTB.

In the results of quantitative data collection, five variables were found to be candidates in the MDR-TB occurrence index, then the index was applied to 3 people with MDR-TB by interviewing retrospective MDR-TB sufferers.

The results of interview from $\mathrm{Mr}$. $\mathrm{H}$ (respondent) showed that he did not have DSC, doing irregular treatment and never drop out. The assessment of MDR-TB occurrence index was shown in Table 3 . Table 3. The Assessment of MDR-TB Occurrence Index of Mr. H

\begin{tabular}{|c|c|c|c|c|}
\hline No & Measurement results & Score & Weight & Weight x Score \\
\hline \multirow[t]{2}{*}{1} & Drug taking advisor & & & \\
\hline & $\begin{array}{l}\text { a. Yes } \\
\text { b. No }\end{array}$ & 1 & 2.33 & 2.33 \\
\hline \multirow[t]{2}{*}{2} & Regular Treatment & & & \\
\hline & $\begin{array}{l}\text { a. Never Forget } \\
\text { b. Ever Forget }\end{array}$ & 1 & 1.73 & 1.73 \\
\hline 3 & $\begin{array}{l}\text { Drug-Side Effect } \\
\text { a. No Drug-Side Effect } \\
\text { b. With Drug-Side Effect }\end{array}$ & $\mathrm{O}$ & 0.73 & $\mathrm{O}$ \\
\hline 4 & $\begin{array}{l}\text { Previous Treatment History } \\
\text { a. Recover or Complete Treatment } \\
\text { b. Failure / Drop Out }\end{array}$ & 1 & 2.35 & 2.35 \\
\hline \multirow[t]{3}{*}{5} & $\begin{array}{l}\text { The Comordibities of DM } \\
\text { a. DM } \\
\text { b. No DM }\end{array}$ & 0 & 0.56 & 0 \\
\hline & TOTAL & & & 6.41 \\
\hline & Index Score & -3.6 & +6.41 & 2.74 \\
\hline
\end{tabular}

It can be concluded in the case of Mr. $\mathrm{H}$, that he has a high risk for the occurrence of MDR-TB. This can be seen from the scores of high occurrence of MDR-TB index that is 2.74 which was higher than Cut off Index score by -0.296. The case in Mr. H was only as an evaluation to the accuracy test of the Index so that the Index can be applied to TB patients to prevent or reduce the risk of MDR-TB.

In Respondent 2, who was Mrs. I, the results of the interview showed that there were 4 variables related to candidate index of MDR-TB occurrence in Mrs. I's MDR history, which were DSC, treatment irregularities and side effects of treatment and the comorbidities. The results of the data were included in the assessment form of MDR-TB occurrence index according to the scores obtained, as in the following Table 4.

It can be concluded in Mrs. I's case that she has a high risk for the occurrence of MDR-TB. This can be seen from the score value of high occurrence index of MDR-TB that is 1.68 , which is higher than Cut off Index score -0.30.

It can be concluded in Mrs. I's case that she has a high risk for MDR-TB. This can be seen from the score value of high occurrence index of MDR-TB that is 2.74, which is higher than Cut off Index score 0.30 . 
Table 4. The Assessment of MDR-TB Occurrence Index of Mrs. I

\begin{tabular}{|c|c|c|c|c|}
\hline No & Measurement results & Score & Weight & Weight x Score \\
\hline \multirow[t]{2}{*}{1} & Drug taking advisor & & & \\
\hline & $\begin{array}{l}\text { a. Yes } \\
\text { b. No }\end{array}$ & 1 & 2.33 & 2.33 \\
\hline 2 & $\begin{array}{l}\text { Regular Treatment } \\
\text { a. Never Forget } \\
\text { b. Ever Forget }\end{array}$ & 1 & 1.73 & 1.73 \\
\hline 3 & $\begin{array}{l}\text { Drug-Side Effect } \\
\text { a. No Drug-Side Effect } \\
\text { b. With Drug-Side Effect }\end{array}$ & 1 & 0.73 & 0.73 \\
\hline 4 & $\begin{array}{l}\text { Previous Treatment History } \\
\text { a. Recover or Complete Treatment } \\
\text { b. Failure / Drop Out }\end{array}$ & $\mathrm{O}$ & 2.35 & $\mathrm{O}$ \\
\hline \multirow[t]{3}{*}{5} & $\begin{array}{l}\text { The Comordibities of Diabetes millitus } \\
\text { a. DM } \\
\text { b. No DM }\end{array}$ & 1 & 0.56 & 0.56 \\
\hline & TOTAL & & & $5 \cdot 35$ \\
\hline & Index Score & -3.6 & 5.35 & 1.68 \\
\hline
\end{tabular}

Table 4. The Assessment of MDR-TB Occurrence Index of Mrs. S

\begin{tabular}{|c|c|c|c|c|}
\hline No & Measurement results & Score & Weight & Weight x Score \\
\hline \multirow[t]{2}{*}{1} & Drug taking advisor & & & \\
\hline & $\begin{array}{l}\text { a. Yes } \\
\text { b. No }\end{array}$ & 1 & 2.33 & 2.33 \\
\hline \multirow[t]{2}{*}{2} & Regular Treatment & & & \\
\hline & $\begin{array}{l}\text { a. Never Forget } \\
\text { b. Ever Forget }\end{array}$ & 1 & 1.73 & 1.73 \\
\hline \multirow[t]{2}{*}{3} & Drug-Side Effect & & & \\
\hline & $\begin{array}{l}\text { a. No Drug-Side Effect } \\
\text { b. With Drug-Side Effect }\end{array}$ & O & 0.73 & O \\
\hline 4 & $\begin{array}{l}\text { Previous Treatment History } \\
\text { a. Recover or Complete Treatment } \\
\text { b. Failure / Drop Out }\end{array}$ & 1 & 2.35 & 2.35 \\
\hline \multirow[t]{3}{*}{5} & $\begin{array}{l}\text { The Comordibities of Diabetes millitus } \\
\text { a. DM } \\
\text { b. No DM }\end{array}$ & 0 & 0.56 & O \\
\hline & TOTAL & & & 6.41 \\
\hline & Index Score & -3.6 & 6.41 & 2.74 \\
\hline
\end{tabular}

The Implementation of MDR-TB Index

The implementation of the research results was using algorithm of MDR-TB occurrence index that can be used by all circles, both community and health workers. The use of this MDR-TB occurrence index algorithm can predict the occurrence of MDR-TB in people with TB, the users no longer need to calculate the MDR-TB index score of TB sufferers. To predict whether a person with TB has a high or low risk of becoming an MDR-TB, the user of this algorithm was required to follow the plot of the scheme, starting from the aspect of DSC availability, regularity in ATD, side effects of ATD, previous result of $\mathrm{TB}$ treatment, and the last one was diabetes mellitus disease. 
Journal of Epidemiology and Public Health (2018), 3(2): 263-276

https://doi.org/10.26911/jepublichealth.2018.03.02.06

\section{REFERENCE}

$\overline{\text { Abouyannis M, Dacombe R, Dambe I, Mpu- }}$ nga J, Faragher B, Gausi F, Ndhlovu H, Kachiza C, et al. (2014). Drug resistance of Mycobacterium tuberculosis in Malawi: a cross-sectional survey. Bull World Health Organ. 92(11): 798-806. doi: 10.2471/BLT.13.126532.

Arockiaraj J, Balaji GS, Cherian VM, Thomas BP, Michael JS, Poonnoose PM (2018). Drug resistant Skeletal Tuberculosis in a tertiary care centre in South India. J Clin Orthop Trauma. 9(1): S44-S48. doi: 10.1016/j.jcot.2017.12.009

Bashar M, Alchabes P, Rom W, Condos R (2001). Increase Incidence of Multidrug-Resistant Tuberculosis in Diabetic Patients on the Bellevue Chest Service, 1987 to 1997 . Chest. 120(5): 1514-9.

Bello SI, Itiola OA (2010). Drug Adherence amongst Tuberculosis Patient in the University of Ilorin Teaching Hospital, Ilorin, Nigeria. African journal of pharmacy and pharmacology 4(3): 109-114.

Bradley P, Gordon NC, Walker TM, Dunn L, Heys S, Huang B, Earle S (2015). Rapid antibiotic-resistance predictions from genome sequence data for Staphylococcus aureus and Mycobacterium tuberculosis. Nat Commun. 6:10063. doi: 10.1038/ncomms10063.

Denkinger CM, Pai M, Dowdy DW (2014). Do we need to detect isoniazid resistance in addition to rifampicin resistance in diagnostic tests for tuberculosis?, PLoS ONE, 9(1). doi: 10.1371/journal.pone.0o84197.

Drug Resistance Survey (DRS) (2016). Multiple Drugs Resistant Tuberculosis survey. Kemenkes RI. www.tbindonesia.or.id/tb-mdr. Accessed April
2017.

Efsen AMW, Schultze A, Miller RF, Panteleev A, Skrahin A, Podlekareva DN, Miro JM, Girardi E, et al. (2018). Management of MDR-TB in HIV coinfected patients in Eastern Europe: Results from the TB:HIV study. Journal of Infection, 76(1): 44-54. doi: 10.1016/j.jinf.2017.10.007.

Fox GJ, Dobler CC, Marais BJ, Denholm JT (2017). Preventive therapy for latent tuberculosis infection-the promise and the challenges, International Journal of Infectious Diseases. International Society for Infectious Diseases, 56: 68-76. doi: 10.1016/j.ijid.2016.11.006.

Ginandjar P, Saraswati LD, Widjanarko, B. (2016). Profile of glycated-hemoglobin, antioxidant vitamin and cytokine levels in pulmonary tuberculosis patients: A cross sectional study at Pulmonary Diseases Center Semarang City, Indonesia', Biomedical Journal. Elsevier Ltd, 39(5): 354-360. doi: 10.1016/j.bj.2016.01.011.

Infodatin (2015). Tuberkulosis. Jakarta: Pusat data dan informasi Kementerian Kesehatan RI, 2015. ISSN 2442-7659.

Jia Z, et al. (2014). Tuberculosis burden in China: A high prevalence of pulmonary tuberculosis in household contacts with and without symptoms, BMC Infectious Diseases. BMC Infectious Diseases, 14(1): 1-7. doi: 10.1186/1471-2334-14-64.

Kigozi G, et al. (2017). Factors influencing treatment default among tuberculosis patients in a high burden province of South Africa, International Journal of Infectious Diseases. The Author(s), 54: 95-102. doi: 10.1016/j.ijid.2016.11.407.

Lee SJ, et al. (2014). Risk factors for latent 
tuberculosis infection in close contacts of active tuberculosis patients in South Korea: A prospective cohort study, BMC Infectious Diseases, 14(1): 1-7. doi: 10.1186/s12879-014-0566-4.

Lin CY, et al. (2016). Risk factors of multidrug-resistant Acinetobacter baumannii recurrence after successful eradication in ventilated patients, Biomedical Journal. Elsevier Ltd, 39(2): 130-138. doi: 10.1016/j.bj.2015.07.001.

Liu X, et al. (2015). Effectiveness of Electronic Reminders to Improve Medication Adherence in Tuberculosis Patients: A Cluster-Randomised Trial, PLoS Medicine, 12(9): 1-19. doi: 10.1371/journal.pmed.1001876.

Matteelli A, et al. (2017). Tuberculosis elimination and the challenge of latent tuberculosis, Presse Medicale. Elsevier Masson SAS, 46(2): e13-e21. doi: 10.1016/j.lpm.2017.01.015.

McBryde ES, et al. (2017). The risk of global epidemic replacement with drugresistant Mycobacterium tuberculosis strains, International Journal of Infectious Diseases. International Society for Infectious Diseases, 56: 14-20. doi: 10.1016/j.ijid.2017.01.031.

McClintock AH, Eastment M, McKinney CM, Pitney CL, Narita M, Park DR, Dhanireddy S, Molnar A (2017). Treatment completion for latent tuberculosis infection: a retrospective cohort study comparing 9 months of isoniazid, 4 months of rifampin and 3 months of isoniazid and rifapentine, BMC Infectious Diseases. BMC Infectious Diseases, 17(1): 146. doi: 10.1186/s12879-017-2245-8.

Mediana (2002). Faktor yang Berhubungan dengan Terjadinya DO PADA Penderita TB Paru di Kabupaten Bandung Tahun 2001, Tesis, Universitas Indo- nesia, Jakarta.

Nagu TJ, Aboud S, Mwiru R, Matee M, Fawzi W, Mugusi F (2015). Multi drug and other forms of drug resistant tuberculosis are uncommon among treatment naïve tuberculosis patients in Tanzania', PLoS ONE, 1O(4): 1-11. doi: 10.1371/journal.pone.0118601.

Outhred AC, Britton PN, Marais BJ (2017) 'Drug-resistant tuberculosis - primary transmission and management', Journal of Infection. Elsevier Ltd, 74, pp. S128-S135. doi: 10.1016/So1634453(17)30203-7.

Pinto CMA, Carvalho ARM (2017). The HIV/TB coinfection severity in the presence of TB multi-drug resistant strains, Ecological Complexity. Elsevier BV, 32: 1-20. doi: 10.1016/j.ecocom.2017.08.001.

Shariff NM, Shah SA, Kamaludin A (2015). Previous treatment, sputum-smear nonconversion, and suburban living: The risk factors of multidrug-resistant tuberculosis among Malaysians. International Journal of Mycobacteriology. Asian African Society for Mycobacteriology, 5(1): 51-58. doi: 10.1016/j.ijmyco.2015.11.001.

Suwanpimolkul G, Kawkitinarong K, Manosuthi W, Sophonphan J, Gatechompol S, Ohata PJ, Ubolyam S, et al. (2017) 'Utility of urine lipoarabinomannan (LAM) in diagnosing tuberculosis and predicting mortality with and without HIV: prospective TB cohort from the Thailand Big City TB Research Network', International Journal of Infectious Diseases. International Society for Infectious Diseases, 59: 96-102. doi: 10.1016/j.ijid.2017.04.017.

Tola H. H. et al. (2016) 'Psychological and educational intervention to improve tuberculosis treatment adherence in 
Journal of Epidemiology and Public Health (2018), 3(2): 263-276

https://doi.org/10.26911/jepublichealth.2018.03.02.06

Ethiopia based on health belief model: A cluster randomized control trial', PLoS ONE, 11(5), pp. 1-16. doi: 10.1371/journal.pone.0155147.

WHO (2013) Multidrug-Resistant Tuberculosis (MDR TB): 2013 Update', Online, (March). Available at: http://www.who.int/tb/challenges/mdr/MDR_TB_FactSheet.pdf.

Yates TA, Khan PY, Knight GM, Taylor JG,
McHugh TD, Lipman M, White RG, et al. (2016). The transmission of Mycobacterium tuberculosis in high burden settings. The Lancet Infectious Diseases. Elsevier Ltd, 16(2): 227-238. doi: 10.1016/S1473-3099 (15): 00499-5. 